\title{
ОСОБЛИВОСТІ ПІДГОТОВКИ МЕДИЧНИХ СЕСТЕР-БАКАЛАВРІВ 3 ЦИКЛУ «ХІРУРГІЯ»
}

\author{
Т. М. Тимченко, Е. Ф. Самарець, С. М. Сушко, Ю. Г. Кікоть \\ Комунальний заклад вищої освіти «Кам'янський \\ медичний коледж» Дніпропетровської обласної ради»
}

У статті описано особливості комплексного підходу в освітньому процесі підготовки медичних сестербакалаврів 3 циклу «Хірургія» із використанням традиційних методів навчання та впровадження новітніх технологій, що дає можливість кваліфіковано виконувати свої професійні обов'язки.

\section{PECULIARITIES OF TRAINING OF BACHELOR NURSES FROM “SURGERY” CYCLE}

\author{
T. M. Tymchenko, E. F. Samarets, S. M. Sushko, Yu. H. Kikot \\ Communal institution of higher education "Kamiansk Medical College" \\ of Dnipropetrovsk Regional Council
}

The article describes the integrated approach in the educational and pedagogical process of training of bachelors in the "Surgery" cycle using traditional teaching methods and introducing new technologies, which allows them to perform their professional duties efficiently.

Вступ. На сьогодні реформування вищої школи в Україні спрямовано як на підготовку фахівців, здатних працювати в нових соціально-економічних умовах, так і на нарощування інтелектуального, духовного, культурного та наукового потенціалу здобувачів освіти [3].

Мета, яку ставлять викладачі Кам'янського медичного коледжу при вивченні хірургії, - це опанування теоретичних знань, насамперед оволодіння здобувачами освіти практичними навичками, методами діагностики хірургічної патології, надання першої медичної допомоги, визначення показань до консервативного та логічно обґрунтованого оперативного лікування з особливостями догляду за хворими даної патології [9, 12].

Основна частина. Підготовка сестер-бакалаврів за умов перебудови сучасної системи охорони здоров'я набуває особливого значення. Завершальною метою навчання медичної сестри-бакалавра $\epsilon$ формування фахівця високого рівня, який може самостійно і кваліфіковано виконувати свої професійні обов'язки. Кам'янський медичний коледж пишається випускниками, які гідно виконують свою місію.

(C) Т. М. Тимченко, Е. Ф. Самарець, С. М. Сушко, Ю. Г. Кікоть, 2021
Так, випускниця медичного коледжу, Кравцова Лариса Семенівна, яка проживає в США, визнана кращою медичною сестрою, яка занесена до Книги Всесвітньої організації лідерів охорони здоров'я у 2016-2017 рр.

Розв'язання завдань поліпшення якості підготовки фахівців, які будуть в майбутньому працювати у відділеннях хірургічного профілю, вимагає від викладачів підвищення рівня викладання, насамперед клінічних дисциплін. Для виконання поставленої мети Кам'янський медичний коледж має два сучасних комфортних навчальних корпуси, гуртожиток з усіма зручностями, а також потужний лікувальнодіагностичний комплекс із хірургії, травматології та нейрохірургії, який розташований на базі міської лікарні швидкої медичної допомоги.

В освітньому процесі належну увагу приділяємо лекціям, які, як правило, передують практичним заняттям. У вступній лекції робимо акцент на тому, що хірургія $\epsilon$ однією з провідних спеціальностей медичної науки, що вивчає захворювання, у лікуванні яких застосовують, в основному, механічні втручання на тканинах організму для виявлення та ліквідації патологічного вогнища. 
В історичному аспекті слухачів лекцій знайомлять 3 життям Миколи Івановича Пирогова (18101881), геніального вченого зі світовим ім'ям, тісно пов'язаним з Україною, якій він віддав понад 25 років своєї плідної праці. Пирогов М. І. поселився у селі Вишня поблизу м. Вінниця, у якому працював до кінця свого життя, надавав медичну допомогу хворим із різноманітними захворюваннями [1].

Микола Іванович Пирогов під час Кримської війни (1853-1856) брав участь в організації військово-польової медичної служби, вперше залучив жінок для надання медичної допомоги пораненим захисникам м. Севастополя. Сестри милосердя, які працювали в операційних та перев'язувальних, на межі можливого і неможливого, всі сили віддали для догляду за пораненими та хворими $[1,7]$. За клопотанням М. І. Пирогова, у 1863 р. прийнято рішення про встановлення посади медичної сестри у військових шпиталях, тому цей рік вважають роком народження спеціальності «Медична сестра» [7].

Так склалася доля, що забальзамоване тіло всесвітньо відомого вченого М. І. Пирогова понад 140 років шанобливо зберігає і вічно зберігатиме наша українська земля [1].

Також на вступній лекції наголошується про роль сучасних українських вчених-хірургів О. О. Шалімова, М. М. Амосова, Д. П. Чухрієнка, М. В. Даниленка, Г. Г. Караванова, М. П. Павловського, Л. Я. Ковальчука та інших, які зробили значний внесок у розвиток як вітчизняної, так і світової хірургії $[6,8]$. Це викликає у здобувачів освіти почуття гордості за українських вчених-хірургів і прищеплює їм любов до цієї спеціальності. Загальновідомо, що у повсякденній роботі медичні сестри хірургічного профілю, особливо операційного блоку, в усіх медичних закладах завжди користуються повагою.

При викладанні лекції використовують як традиційні наочні посібники (муляжі, таблиці, плакати, скелет, фантоми), так й інноваційні технології (мультимедійні презентації, електронні підручники, показ відеофільмів, тестування, навчальні тренінги). Викладач наводить конкретні приклади з особистого досвіду роботи хірурга. Це викликає допитливість у здобувачів освіти, підвищує інтерес до лекції, що робить її більш доступною, сприяє кращому запам'ятовуванню і опануванню головних моментів даного захворювання, про яке йде мова.

Для самостійної позааудиторної підготовки до занять, крім традиційних посібників, які передбачені навчальною програмою, рекомендуємо використовувати спеціалізовану медичну літературу періодичних видань. Отримана інформація з додаткової літератури, згідно з профілем, покращує якісний рівень знань майбутніх фахівців.

Особливе місце у вивченні хірургії посідають практичні заняття з використанням відеоматеріалів, оскільки при вивченні конкретної патології не завжди є можливість показати відповідного хворого. На допомогу приходять новітні технології - відеоматеріали, в яких відображені різноманітні реальні клінічні ситуації з найбільш яскравою картиною хвороби та основними методами діагностики, що дозволяє майбутньому фахівцю закріпити теоретичні знання, опрацювати практичні навички та приймати правильні рішення.

Для поліпшення якості підготовки до практичних занять усі здобувачі освіти знайомляться з переліком симптомів і синдромів, розроблених викладачами коледжу, які відображають найбільш ймовірний патологічний процес. Так, для синдрому «гострого живота» виділено основні симптоми при гострому апендициті, гострому холециститі, проривній виразці шлунка і дванадцятипалої кишки, гострому панкреатиті, гострій непрохідності кишечника, защемленій грижі, тромбозі брижових судин та ін.

У навчальних кімнатах у присутності викладача майбутні фахівці відпрацьовують один на одному правильність виконання тих чи інших прийомів, що відображають певні симптоми захворювання. Спираючись на чіткі критерії, здобувачі освіти встановлюють діагнози хірургічних захворювань.

Викладач звертає особливу увагу майбутніх спеціалістів на те, що основою встановлення діагнозу, як і раніше, залишаються дані ретельно зібраного анамнезу і результати фізикального дослідження (огляд, пальпація, перкусія, аускультація) [4]. Якість своєчасної діагностики, особливо в невідкладній хірургії, істотно впливає на результати лікування хворих, бо як казали древні: «Diagnosis certa - ulla therapie fundamentum» («Достовірний діагноз - основа правильного лікування») [4]. Дані старанно зібраного анамнезу, фізикального обстеження складають основу осмисленого застосування додаткових спеціальних діагностичних методів: рентгенологічних, ультразвукових, комп'ютерної, магнітно-резонансної томографії та ін.

Позитивну роль в успішному навчанні відіграють інформаційно-комунікаційні технології, що допо- 
магають підвищенню якості підготовки майбутніх спеціалістів. На сучасному етапі освіти більшість закладів вищої освіти віддає перевагу інноваційним методам навчання $[2,3,5]$.

Впровадження в педагогічний процес інноваційних технологій передбачає набуття змін у методологічних підходах проведення занять. Ми впевнені в тому, що повинен бути розумний підхід до поєднання традиційних методів навчання з інноваційними.

Важливим моментом у підготовці майбутніх фахівців в освітньому процесі $\epsilon$ формування у здобувачів освіти клінічного мислення з розглядом тематичних хворих та належний догляд за ними залежно від захворювання. Великий обсяг медичних втручань вимагає від медичної сестри-бакалавра хірургічного профілю професійного підходу - постійного вдосконалення клінічних і практичних навичок $[3,9,12,13]$.

Під час проведення практичних занять у закладах охорони здоров'я, на жаль, виникають певні конфліктні ситуації. Незважаючи на суворе дотримання медичної етики та деонтології відносно хворого і його родичів, пацієнти відмовляються від огляду і виконання маніпуляцій (внутрішньом'язових ін'єкцій, інфузійної терапії, перев'язки тощо), мотивуючи це тим, що вони хочуть, щоб це виконувала досвідчена медсестра $[9,10]$. Через недостатнє фінансування охорони здоров'я хворі змушені купувати значну кількість медикаментів, шприци, одноразові системи для внутрішньовенних інфузій, рукавички та інше. У зв'язку зі значними фінансовими витратами, пацієнти потребують надання кваліфікованого медичного обслуговування і відмовляються від «практикантів». Тому навички різноманітних маніпуляцій доводиться ретельно відпрацьовувати в навчальних кабінетах на фантомах.

У зв'язку з пандемією коронавірусної інфекції COVID-19, у лікувальних закладах дотримуються санітарно-протиепідемічного режиму, тому проведення практичних занять зі здобувачами освіти в лікарнях обмежено. Сучасні комп'ютерні технології дозволяють наочно виконувати техніку певних практичних маніпуляцій, проводити діагностичні та лікувальні процедури з наступним відпрацюванням їх техніки на муляжах.

\section{СПИСОК ЛІТЕРАТУРИ}

1. Антощук К. Ф. Зв'язки М. І. Пирогова з українцями / К. Ф. Антощук // Пироговські лекції : матеріали наукового конгресу «IV Пироговські міжнародні читання», присвя-
При необхідності або за бажанням майбутні фахівці мають можливість самостійно, за допомогою інформаційно-комунікаційних технологій, переглянути зміст теми заняття. Це поліпшує якість підготовки медичної сестри-бакалавра до практичної роботи і підвищує ефективність навчального процесу.

Відпрацьовуючи на муляжах медичні маніпуляції, які пов'язані з внутрішньом'язовими ін'єкціями, внутрішньовенними інфузіями, перев'язками тощо, викладач завжди наголошує здобувачам освіти на обов'язковому дотриманні правил асептики і антисептики незалежно від того, в якому відділенні будуть вони працювати [11].

Безумовно, запровадження інновацій відіграє важливу роль у формуванні молодого спеціаліста. Але, незважаючи на впровадження новітніх технологій у навчання в Кам'янському медичному коледжі сестра-бакалавр була готова до роботи в хірургічному відділенні, маніпуляційному кабінеті та в операційній.

3 метою оптимізації освітнього процесу на роботу до коледжу запрошено викладачів Дніпровської державної медичної академії: докторів і кандидатів медичних наук, професорів і доцентів. Можна констатувати, що це сприяло підвищенню якості освіти.

Одним із пріоритетів у освітньому процесі стало навчити майбутніх фахівців навичкам проведення пошуків наукових досліджень [14]. Отримані в коледжі базовий та підвищений рівні підготовки з хірургії з елементами науково-дослідної роботи сприятимуть різнобічному інтелектуальному розвитку особистості при виконанні своїх професійних обов'язків.

Перші кроки в цьому напрямку зроблено.

Висновки. Комплексний підхід в освітньому процесі з використанням традиційних методів навчання з впровадженням новітніх технологій сприяє вирішенню основних завдань - більш поглибленої підготовки з хірургії медичної сестри-бакалавра. Набуття теоретичних знань і практичних навичок з елементами науково-дослідної роботи дає можливість самостійно та кваліфіковано виконувати свої професійні обов'язки з дотриманням медичної етики і деонтології. ченого 200-річчю з дня народження М. І. Пирогова (Вінниця, 2-5 червня). - Вінниця : Вінницький національний медичний університет ім. М. І. Пирогова, 2010. - С. 26-30. 
2. Булгакова Н. В. Інноваційні технології навчання при викладанні дисциплін хірургічного циклу / Н. В. Булгакова, Н. О. Кравець // Медсестринство. - 2014. - № 4. C. $17-18$.

3. Варава О. Б. Модель розвитку інформаційно-аналітичної компетентності майбутніх сестер / О. Б. Варава // Медсестринство. - 2018. - № 3. - С. 38-41.

4. Даценко Б. М. Комплексная диагностика в неотложной абдоминальной хирургии : монография / Б. М. Даценко, Ш. Ф. Ибишов. - К. : Здоров'я, 1991. - 264 с.

5. Гук-Лешневська 3. О. Ведення активного навчання зі студентами випускного курсу з внутрішньої медицини / З. О. Гук-Лешневська, О. М. Радченко, О. Р. Слаба // Сучасні підходи до вищої медичної освіти в Україні : матеріали XIV Всеукраїнської науково-практичної конференції з міжнародною участю, присвяченої 60-річчю ТДМУ (Тернопіль, 18-19 травня 2017 р.) : у 2 т. - Тернопіль : ТДМУ, 2017. - Т. 2. - С. 42.

6. Кіт О. М. Медсестринство в хірургії : підручник / О. М. Кіт, О. Л. Ковальчук, Г. Т. Пустовойт. - Тернопіль : Укрмедкнига, 2002. - 494 с.

7. Кланца О. П. Идеал сестры милосердия (Памяти Екатерины Михайловны Бакуниной) / О. П. Кланца, 3. С. Мартынова, Л. И. Фоменко // Пироговські лекції : матеріали наукового конгресу «IV Пироговські міжнародні читання», присвяченого 200-річчю з дня народжен- ня М. І. Пирогова. - Вінниця : Вінницький національний медичний університет ім. М. І. Пирогова.

8. Клінічна хірургія / за ред. Л. Я. Ковальчука, В. Ф. Саєнка, Г. В. Книшова. - Тернопіль : Укрмедкнига, 2000. T. 1. $-536 \mathrm{c}$.

9. Муратов С. Н. Хирургические болезни с уходом за больными : учебник для медсестр. отд-ний мед. уч-щ / С. Н. Муратов. - М. : Медицина, 1981. - 336 с.

10. Попович Я. М. Особливості медичної етики та деонтології / Я. М. Попович // Медсестринство. - 2018. № 3. - С. 11-14.

11. Романова І. І. Асептика і антисептика в роботі медичної сестри хірургічного профілю / І. І. Романова // Медсестринство. - 2018. - № 3. - С. 48-51.

12. Практикум з медсестринства в хірургії / Р. О. Сабадишин, О. В. Маркович, В. О. Рижковський, Б. З. Чижишин. Вінниця : Нова книга, 2017. - 360 с.

13. Сестринська справа : підручник (BН3 I-III р. а.) / Н. М. Касевич ; за ред. В. І. Литвиненка. - К. : Медицина, 2017. - 816 c.

14. Сидоренко М. А. Организация и формы научно-творческой деятельности студентов в медицинском коледже / М. А. Сидоренко // Научное пространство Европы - 2007 : материалы III международной научно-практической конференции (16-30 апреля 2007 г.). - Днепропетровск : Наука и образование, 2007. - Т. 8. - С. 52-53. 